\title{
What is New in COVID-19 and What We Need to Do Against This Pandemic Infection? A Comparative Review
}

\author{
Sadaf Naeem ${ }^{1}$, Yousra Shafiq ${ }^{2}$, Muhammad Arif Asghar ${ }^{2, *}$
}

${ }^{1}$ Department of Pharmacology, Faculty of Pharmacy, Jinnah Sindh Medical University, Rafiqui H.J Shaheed Road, Karachi-75510, Pakistan

${ }^{2}$ Department of Pharmaceutics, Faculty of Pharmacy, Jinnah Sindh Medical University, Rafiqui H.J Shaheed Road, Karachi-75510, Pakistan

Authors' Contributions

1,2 Conception \& study design

2 Data Collection \& Processing

1, 3 Data Analysis and/or interpretation

1, 2, 3 Drafting of Manuscript

2, 3 Critical Review

\section{Acknowledgement}

Prof Dr Kamran Hameed for his guidance and

supports.

Article info.

Received: May 4, 2020

Accepted: September 7, 2020

Funding Source: Nil

Conflict of Interest: Nil

Cite this article: Naeem S, Shafiq Y, Asghar MA. What is new in COVID-19 and what we need to do against this pandemic infection? A comparative review. RADS J Pharm Pharm Sci. 2020; 8(2):116-125.

*Address of Correspondence Author: sadafnaeem@jsmu.edu.pk yusra_ali_81@hotmail.com m.arifasghar@hotmail.com

\section{ABSTRACT}

Background: Initially, large number of COVID-19 cases reported from Wuhan City, China, reflected that this is likely the zoonotic origin of COVID19. In March, 2020; it has since been declared a serious pandemic infection by the World Health Organization (WHO).

Objective: The main objective of this review was to addressed what gaps still exist. Many researchers have reported the many common characteristics of COVID-19 virus in comparison with other pandemic viruses, while the major differences are discussed in this review.

Method: In this review, we investigated the general characteristics of COVID19 its diagnosis and other preventive measures in comparison with other pandemic viruses that we know or we need to know.

Results: All reported corona viruses belong to the one genus and family Coronavirus and Coronaviridae. The COVID-19 virus spreads easily and exponentially multiple times compares to other viruses. It can be divided into four antigenic groups, HKU1, NL63, 229E and OC43. The case mortality rate of this pandemic is $1.68 \%$, compared to other pandemics in their first outbreaks, including the great pandemic influenza (0.2\%), SARS-CoV $(10 \%)$, MERS-CoV (34\%), and Ebola (50\%). Laboratory findings related to COVID-19 include elevated levels of D-dimer, Alanine transaminase (ALT), LDH (lactate dehydrogenase), C-reactive protein (CRP), creatine kinase and prothrombin times.

Conclusion: This comparison based review will help to understand the biology, potential risk and preventive measures of COVID-19 and provide cognizance about what we need to do against this pandemic which victimized more than 200 countries up to the present time.

Keywords: COVID-19, Pandemic, Characteristics, SARS-CoV-2 


\section{INTRODUCTION}

The outbreak of Influenza Pandemic in 1918-1920 represents a plausible worst-case scenario, particularly in the United States of America (USA) with global reach like present scenario of COVID-19. The former's $2 \%$ death per total population due to the Influenza Pandemic in its $1^{\text {st }}$ outbreak of the total population translates into more than 150 million peoples deaths today [1]. Further, that death rate due to pandemic corresponds to declines in Gross domestic product (GDP) and consumption worldwide by $6 \%$ and $8 \%$, respectively. That influenza pandemic was also associated with real rates declines of shortterm bills and return on stocks [2].

In the same way as the 1st outbreak of Influenza Pandemic made dreadful advent in USA, COVID-19 follow the same footstep, but this time whole population of the world joins to make these dreadful memories. After initial confirmed case appeared officially in Wuhan city of China in January 15, 2020; to this point the WHO has confirmed $25,169,549$ COVID-19 infected cases worldwide as shown in Table 1 till August 30th 2020 [3]

Of these confirmed cases globally, 846,778 (3.36\%) infected peoples have succumbed to the COVID-19 virus so far. Figure 1 also revealed the drastic escalation in death rates altogether, particularly in USA and Brazil [3].

The majority of the confirmed cases have been reported in USA 6,139,078 (N) while confirmed deaths due to this rotten virus have been witnessed in same country $186,855(\mathrm{~N})$ that is about $24.3 \%$ and
$0.74 \%$ of the total confirmed cases and deaths altogether respectively [4]. It is important to note that, Russia have the significantly lower fatality rate 17,025 (N) which is about $1.72 \%$ of total $985,346(\mathrm{~N})$ confirmed cases reported in Russia alone [5].

Human pathogenic of different reported CoV subtypes are associated with mild clinical signs and symptoms [6]. However, previous reported infections such as SARS-CoV and MERS-CoV coronavirus are the two notable exceptions which led to 858 and 774 fatalities respectively [7]. This mirror image or must say the more horrifying dominance of this COVID-19 virus reaches anything close to other pandemic viruses such as influenza virus, SARS-CoV, MERSCoV, and Zaire ebolavirus seems remote, advances in public health,

given epidemiological differences and mitigating policies at play. Unlike seasonal flu and other pandemic viruses, for which there is a prophylaxis treatment available to protect people from infections, there are no vaccine or drugs for COVID-19 prevention or cure. So, if there is a silver lining from this dark cloud of frightening COVID-19, it has to be needed more focus and closer attention to prevailed the knowledge about this virus and preventive measures to conquered from this viral disease. Therefore, this brief review provides the more scientific knowledge of COVID-19 virus in comparison of other pandemic viruses and also gives awareness about what we needs to do against this perturbing viral infection to prevail this pandemic.

Table 1. Report of COVID-19 epidemiology worldwide and in top five prevalent countries till $30^{\text {th }}$ August2020.

\begin{tabular}{|c|c|c|c|c|}
\hline Region & Total cases & $\begin{array}{c}\text { Total Deaths } \\
\mathbf{N}(\%)\end{array}$ & $\begin{array}{c}\text { Total Recovered } \\
\mathbf{N}(\%)\end{array}$ & $\begin{array}{c}\mathbf{1}^{\text {st }} \text { officially } \\
\text { confirmed case }\end{array}$ \\
\hline World & $25,169,549$ & $846,778(3.36)$ & $17,509,305(69.56)$ & 10-Jan-2020 \\
\hline USA & $6,139,078$ & $186,855(3.04)$ & $3,408,799(55.52)$ & $20-J a n-2020$ \\
\hline Brazil & $3,846,965$ & $120,498(3.13)$ & $3,006,812(78.16)$ & $25-F e b-2020$ \\
\hline India & $3,542,733$ & $63,657(1.79)$ & $2,713,933(76.60)$ & $30-J a n-2020$ \\
\hline Russia & 985,346 & $17,025(1.72)$ & $804,383(81.63)$ & $31-J a n-2020$ \\
\hline Peru & 639,435 & $28,607(4.47)$ & $446,675(69.85)$ & 06-Mar-2020 \\
\hline
\end{tabular}




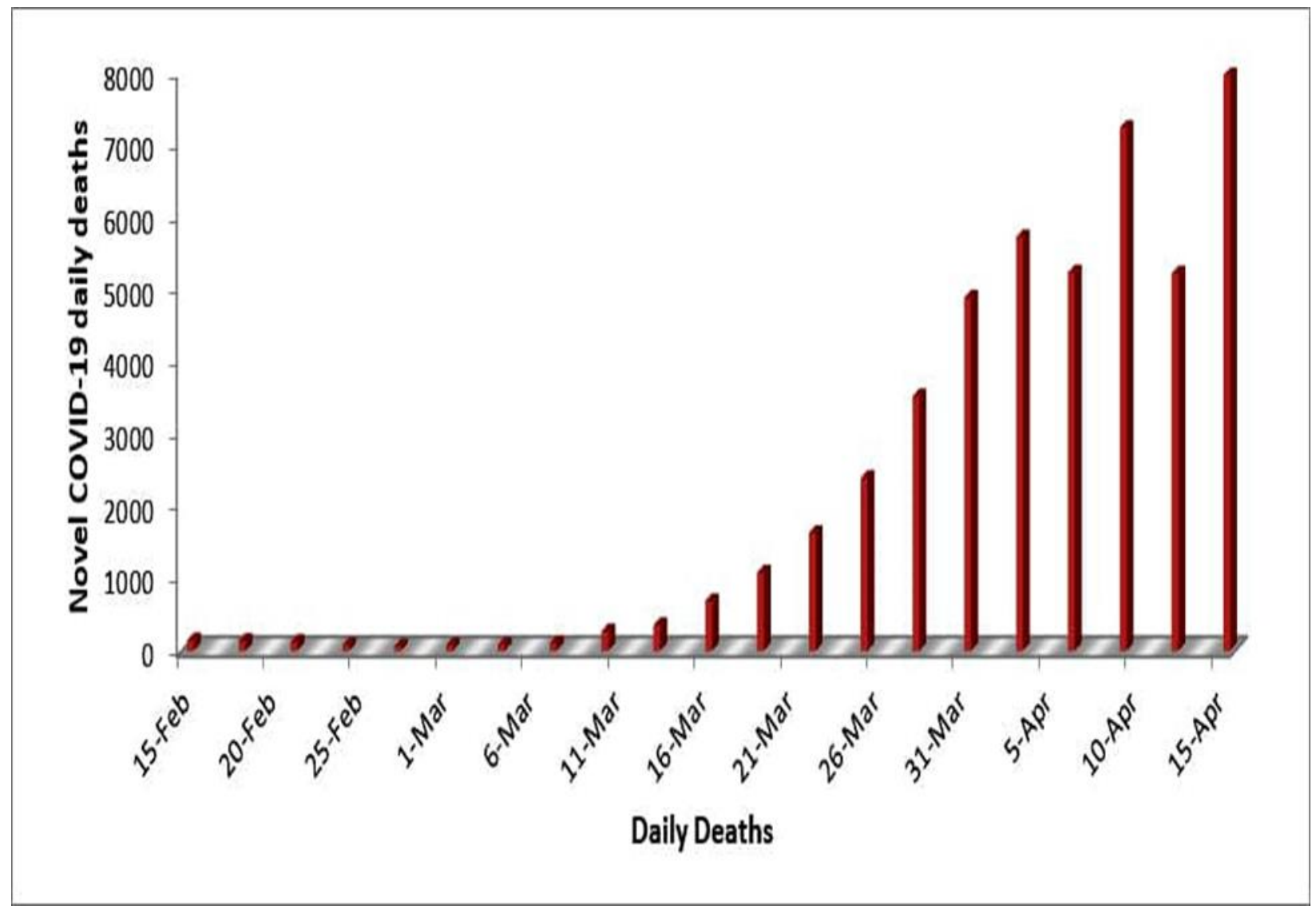

Figure 1. Death rate per day due to COVID-19 worldwide.

\section{REVIEW}

\section{What's new in Covid-19}

\section{Genomic overview of COVID-19}

To date, literatures reported many of the characteristics of COVID-19 virus are common to other known viruses, but combinations of factors are different. All reported corona viruses belong to the one genus and family Coronavirus and Coronaviridae respectively [8]. Under the electron microscope Coronaviruses have ribonucleic acid (RNA) envelope with prickles like projections and diameter in the range of $60 \mathrm{~nm}$ to $140 \mathrm{~nm}$ [9]. An even smaller protein has recently been shown to be an integral membrane protein of the viral envelope [10]. Inside the envelope is a ribonucleoprotein (RNP) core, which comprises the RNA genome and a single species of nucleocapsid protein N. A long helix of size 14 to 16 $\mathrm{nm}$ in viral RNA also observed in electron microscopy technique [11]. Initially, serological analysis was used to differentiate coronavirus species and showed that they could be divided into four antigenic groups, HKU1, NL63, 229E and OC43 have been usually produced severe respiratory problems [12]. The species and group divisions were subsequently refined by monoclonal antibody analysis and nucleotide sequencing [10]. Moreover, University of Karachi institute named "Dr. Panjwani Center for Molecular Medicine and Drug Research" has been reported the whole genome sequence of Coronavirus (SARS-CoV-2)," they found nine mutations (changes in the Deoxyribonucleic acid (DNA)) in the different regions of the genome of COVID-19 virus found in another region of the world when compared to the sequence reported from Wuhan (China) [13]. In addition, Zhou et al, (2020) reported a bat-derived CoV, which is denoted as RmYN02, identified during metagenomic analysis of bats. Interestingly, this RmYN02 shares 93.3\% nucleotide very much identical with SARS-CoV-2 genome [14].

\section{Easy contagion}

The COVID-19 virus spreads easily and exponentially multiple times. "It is estimated that, an infected person will infect at least 2 or 3 people if they don't take any preventive measures [15]. According to WHO "there are also reported cases of 'super contaminators', that is, infected people who were not well understood, 
contaminate a large population region wide [16]. This is also increased due to the lack of immunity of the global population, especially observed in European countries, as it is a new virus." Moreover, researchers pointed out that the COVID-19 spreads more quickly because it is practically "invisible" in most of the cases, around $50 \%$; it does not or cause mild symptoms similar to flu or a common cold. In this case, a person is highly contagious during virus incubation period [17]. In contrast, in other pandemics infections, people are not contagious until they develop symptoms like in Ebola virus.

\section{Origin and spread}

In December 2019, China informed WHO to several cases of pneumonia like condition in its city called Wuhan, in the central province of Hubei [18]. At that time COVID-19 was not made any trademark in pandemic infectious arena. The health care officials of China ruled out the possibility of recurrence of the old SARS-CoV an illness that also originated from China and killed more than 770 people worldwide in 20022003 as presented in Table 2 [7]. ]. In January $8^{\text {th }}$, the first journal named "The British Medical Journal" reported this emerging respiratory disease as an outbreak of pneumonia of unknown cause in Wuhan [19]. After that, WHO published a report in the Journal of Medical Virology the novel virus was COVID-19 and belonging to the coronavirus family, which includes SARS-CoV [16]. The case mortality rate of this pandemic is $1.68 \%$, which are growing more hurriedly compared to other pandemics in their first outbreaks, including the great pandemic influenza $(0.2 \%)$, SARS-CoV (10\%), MERS-CoV (34\%), and Ebola $(50 \%)$ as shown in Figure 2 [3,11,20,21].

Table 2. General characteristics of different viruses in comparison with COVID-19.

\begin{tabular}{|c|c|c|c|c|c|}
\hline Characteristics & COVID-19 & SARS & MERS & Influenza & Ebola \\
\hline Symptoms & $\begin{array}{l}\text { Dry cough, } \\
\text { Fever, } \\
\text { Tiredness, } \\
\text { difficulty in } \\
\text { breathing }\end{array}$ & $\begin{array}{c}\text { Fever, Dry } \\
\text { cough, } \\
\text { Shortness of } \\
\text { breath }\end{array}$ & $\begin{array}{c}\text { Fever, } \\
\text { cough, } \\
\text { shortness of } \\
\text { breath }\end{array}$ & $\begin{array}{c}\text { Fever, cough, } \\
\text { headache, muscle and } \\
\text { joint pain, }\end{array}$ & $\begin{array}{c}\text { Fever, } \\
\text { Fatigue, } \\
\text { Muscle pain, } \\
\text { Headache }\end{array}$ \\
\hline $1^{\text {st }}$ appear & 2019 & 2002 & 2012 & 1918 & 1976 \\
\hline $\begin{array}{l}\text { Age infected } \\
\text { (Years) }\end{array}$ & $\begin{array}{l}\text { All age } \\
\text { group }\end{array}$ & $\begin{array}{l}\text { All age } \\
\text { group }\end{array}$ & $\begin{array}{l}\text { All age } \\
\text { group }\end{array}$ & $15-35$ & $25-40$ \\
\hline $\begin{array}{c}\text { Incubation } \\
\text { (Days) }\end{array}$ & 14 & 7 & 5 & 2 & 11 \\
\hline Transmission & $\begin{array}{l}\text { Person to } \\
\text { person } \\
\text { (not } \\
\text { airborne) }\end{array}$ & $\begin{array}{l}\text { Person to } \\
\text { person } \\
\text { (airborne } \\
\text { virus) }\end{array}$ & $\begin{array}{l}\text { Person to } \\
\text { person } \\
\text { (airborne } \\
\text { virus) }\end{array}$ & $\begin{array}{c}\text { Secretion } \\
\text { (airborne virus) }\end{array}$ & $\begin{array}{l}\text { Blood or } \\
\text { body fluids } \\
\text { (Not } \\
\text { airborne } \\
\text { virus) }\end{array}$ \\
\hline Infected organs & $\begin{array}{c}\text { Respiratory } \\
\text { system }\end{array}$ & $\begin{array}{c}\text { Respiratory } \\
\text { system }\end{array}$ & $\begin{array}{c}\text { Respiratory } \\
\text { system }\end{array}$ & hematopoietic organs & $\begin{array}{l}\text { Immune } \\
\text { system }\end{array}$ \\
\hline $\begin{array}{l}\text { Countries } \\
\text { infected }\end{array}$ & 210 (So Far) & 26 & 27 & 43 & 11 \\
\hline Outbreak period & 2020 & 2003 & 2014 & $1918-1920$ & $2014-2106$ \\
\hline Diagnosis tools & $\begin{array}{c}\text { PCR (RT- } \\
\text { PCR) }\end{array}$ & $\begin{array}{c}\text { PCR (RT- } \\
\text { PCR) }\end{array}$ & $\begin{array}{c}\text { PCR (RT- } \\
\text { PCR) }\end{array}$ & Antigen detection, & ELISA, PCR \\
\hline Causes & $\begin{array}{c}\text { SARS- } \\
\text { cOV2 virus }\end{array}$ & $\begin{array}{l}\text { SARS-CoV1 } \\
\text { virus }\end{array}$ & $\begin{array}{c}\text { MERS-CoV } \\
\text { virus }\end{array}$ & Influenza virus & $\begin{array}{c}\text { Zaire } \\
\text { ebolavirus }\end{array}$ \\
\hline Prevention & $\begin{array}{c}\text { No vaccine } \\
\text { yet }\end{array}$ & $\begin{array}{c}\text { No vaccine } \\
\text { yet }\end{array}$ & $\begin{array}{c}\text { No vaccine } \\
\text { yet }\end{array}$ & Vaccination & Vaccination \\
\hline Treatment & Supportive & Supportive & Supportive & $\begin{array}{c}\text { Oseltamivir, } \\
\text { Corticosteroids }\end{array}$ & Supportive \\
\hline
\end{tabular}




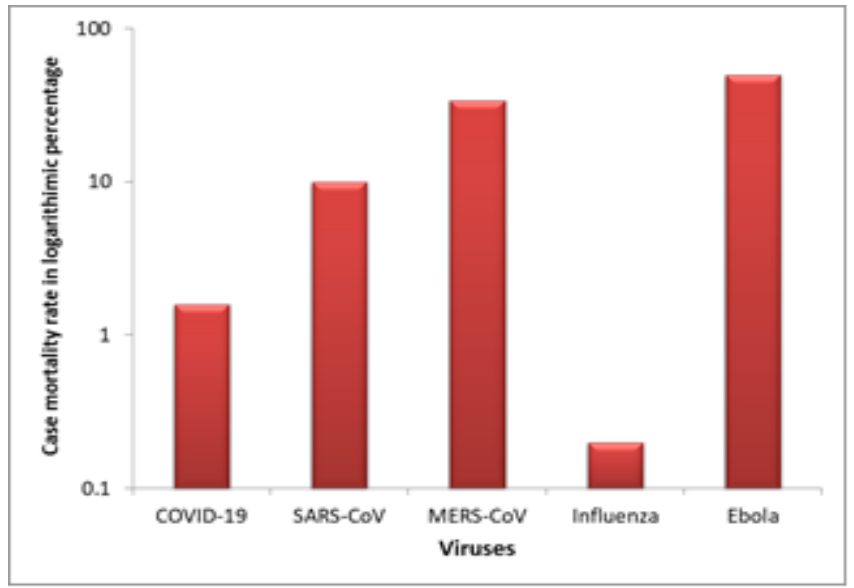

Figure 2. Case mortality rate in logarithmic percentage due to five pandemic viruses worldwide.

At this point, this value is not much higher compared to others, but the alarming sign of this pandemic is that the rate of case mortality has found in only three months since its outbreak. Moreover, the confirmed cases $\left(0.32 \%\right.$ of total world population, till August $30^{\text {st }}$ 2020). At this point, this value is not much higher compared to others, but the alarming sign of this pandemic is that the rate of case mortality has found in only three months since its outbreak. Moreover, the confirmed cases $(0.32 \%$ of total world population, till August $30^{\text {st }} 2020$ ) are also intensifying more briskly globally, particularly in the USA which makes an identical foot-mark as Influenza in its $1^{\text {st }}$ two years outbreak period as revealed in Figure 3 [16].

Coronaviruses are spreading now through an infected person generated when a person sneeze or cough, or touching a droplets land surface and then touch their hands to one's face or nose [22]. Similar spreading was observed in SARS-CoV and MERS-CoV while contingency of COVID-19 is found much higher than other pandemics [23].

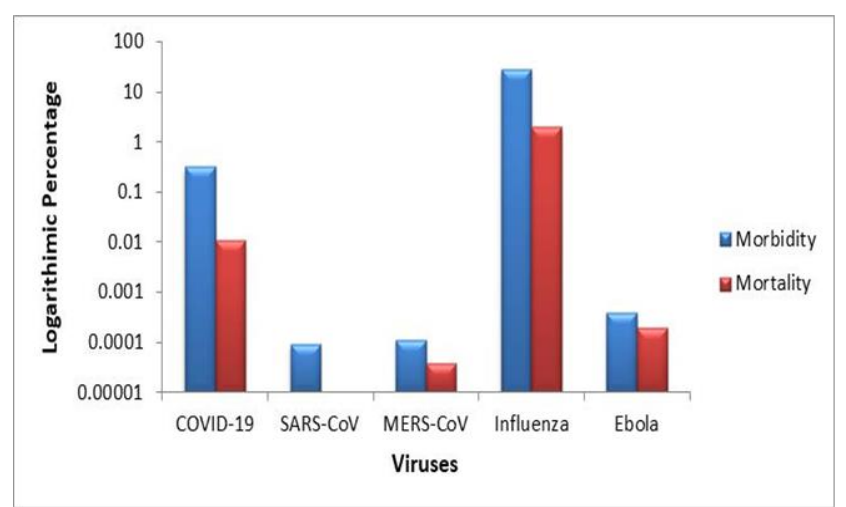

Figure 3. Morbidity and mortality in logarithmic percentage due to initial outbreaks of five pandemic viruses worldwide. Figure 4 showed the age-wise distribution of fatality rates of COVID-19 in comparison with other four pandemic viruses [2, 3, 7, 24].Commonly, older aged patients are more prone to surrender their lives compared to younger ones in almost all pandemic viruses except the great pandemic of influenza in which fatality rate was much higher in younger ones.

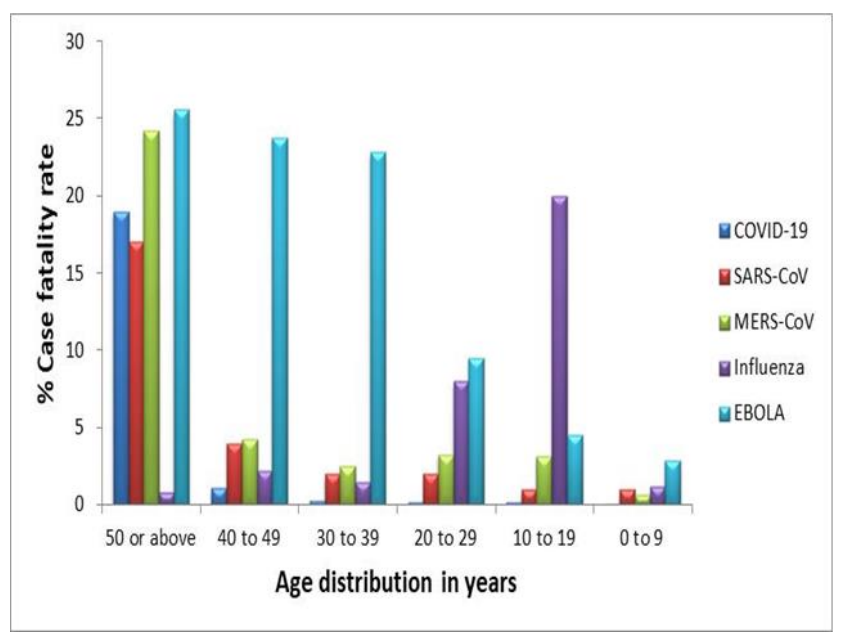

Figure 4. Age-wise distribution of case fatality rates in percentage due to five pandemic viruses.

\section{Clinical and Laboratory Features}

Basically COVID-19 has three worsening clinical features: initially at the onset of infection, a mild malaise along with upper respiratory tract symptoms, leading to the condition of a mild pneumonia, at later stage, symptoms becomes more worsen leads to the acute respiratory distress [25]. Once symptoms appear, the patient takes 6 to 14 days to develop severity of disease and even death ranged within 6 to 41 days [15]. This period range depends on the patient's age and stability of their immune system. It had been shorter among patients up to 70-years old compared with those who are young and below 70 years [26]. According to WHO reports on COVID-19 symptoms are wide-ranging, starting from an asymptomatic state to acute upper respiratory syndrome and various multi organ dysfunctions [27]. Fever, cough, dyspnea, pharyngitis, headache, tiredness, myalgia and leading to pneumonia are commonly found in observed in COVID-19 infected patients [15]. Dryness of lips and Conjunctivitis has also been reported in various patients [28]. In severely victimized patients pneumonia has been reported with bilateral and/or multilobar involvement of lung by a chest CT scan [29]. However, there has been abnormal manifestation like anemia, acute 
Table 3. Factors affecting poor outcomes of studied viruses.

\begin{tabular}{|c|c|c|c|c|c|}
\hline \multirow{2}{*}{ Factors } & \multicolumn{5}{|c|}{ Viruses } \\
\cline { 2 - 6 } & COVID-19 & SARS-CoV & MERS-CoV & Influenza & Ebola \\
\hline Increased age & Advanced age & Advanced age & Advanced age & $\begin{array}{c}\text { No significant } \\
\text { effect }\end{array}$ & $\begin{array}{c}\text { No significant } \\
\text { effect }\end{array}$ \\
\hline Male sex & $\begin{array}{c}\text { No significant } \\
\text { effect }\end{array}$ & Female sex & Male sex & $\begin{array}{c}\text { No significant } \\
\text { effect }\end{array}$ & $\begin{array}{c}\text { No significant } \\
\text { effect }\end{array}$ \\
\hline $\begin{array}{c}\text { Increased } \\
\text { differential WBCs }\end{array}$ & Neutrophils & Neutrophils & Neutrophils & Increased & Increased \\
\hline Increase urea & $\begin{array}{c}\text { No significant } \\
\text { effect }\end{array}$ & $\begin{array}{c}\text { No significant } \\
\text { effect }\end{array}$ & $\begin{array}{c}\text { No significant } \\
\text { effect }\end{array}$ & Increased & Increased \\
\hline Hyponatremia & $\begin{array}{c}\text { No significant } \\
\text { effect }\end{array}$ & $\begin{array}{c}\text { No significant } \\
\text { effect }\end{array}$ & $\begin{array}{c}\text { No significant } \\
\text { effect }\end{array}$ & Increased & Increased \\
\hline \multicolumn{7}{|c|}{ Multivariate analysis } & Hepatitis B & Hepatitis B & $\begin{array}{c}\text { Pulmonary } \\
\text { disease }\end{array}$ & Malaria \\
\hline $\begin{array}{c}\text { Other co-morbid } \\
\text { disease }\end{array}$ & CVD & Heared
\end{tabular}

${ }^{*} \mathrm{P}>0.05$ What we need to do against this Pandemic

respiratory distress, anosmia, and incidence of acute cardiac injury that led to death [15]. Very nearly or almost similar symptoms were observed in all these pandemic while the incubation period of COVID-19 is much higher than others (Table 3) [30-32].

Laboratory findings related to COVID-19 include elevated levels of D-dimer, Alanine transaminase (ALT), LDH (lactate dehydrogenase), C-reactive protein (CRP), creatine kinase and prothrombin times [33].

A marked reduction in lymphocytes particularly CD4 and CD8 can also observe in the early stages of the infection [34]. Patients in the ICU have shown higher levels of interleukins such as IL 2, 7, and 10, MIP1A (macrophage inflammatory protein alpha), GCSF (granulocyte colony-stimulating factor) and TNF- $\alpha$ (tumor necrosis factor- $\alpha$ ) [35, 36]. Other abnormal findings also reported, including deficiency in cellular immune, coagulation activation, renal injury, myocardial injury, and hepatic injury. The elevations in counts of neutrophils, ferritin, blood urea, D-dimer, and creatinine levels are commonly observed in all infected persons [37]. These increased in differential white blood cells (WBCs) counts, especially neutrophils counts are the common factors affecting poor outcomes in all pandemic viruses (Table 3) [36, 38-40]. Moreover, cardiovascular diseases are the most common co-morbid conditions found in COVID19 confirmed fatality cases using multivariate analysis at $\mathrm{P}>0.05$.

\section{How long the infected patients in quarantine and} self-isolation

The length of the quarantine is approximated around 14 days while at this point it is unrevealed that for how long a patient is contagious after infection. In China, many patients reported the similar symptoms after full recovery period. Hence the importance of generalized lockdown and social distancing measures. Use of n95 mask is advisable during meetings and traveling. One study reported that the screening test for virus can be found positive in patients for 8 to 37 days, with an average of around 20 days [36].

Many developed countries lack of preparation puts them in the horrible face of this pandemic, due to the slow reaction of the citizens and higher authorities in combined. In most of the cases it has been observed that, epidemics always have political and economic elements. Health and other concern authorities often hesitate to apply unpopular preventive measures, which can cause panic in citizens and potentially reduce the economic growth. Such hesitation, from China to the Europe and now in the USA, was also a key factor in the current situation. Now USA is facing a great problem and now 48,000 cases in only New York has been reported. Globalization also plays an important in the facilitation of the virus spread. The fact was also happened and observed by whole world in a city of 11 million inhabitants, hyper connected by land, air and sea in China, a country considered to be the "factory of the world" has facilitated this situation [41]. It's high time now to prepared ourselves against this pandemic and takes global measures which will 
be more disciplined when it comes to ourselves protection and will applying isolation measures, decision of early lock own in pandemic areas and self-isolation to prevent massive spread of this COVID-19".

\section{The contagion}

It is more important to aware whole population about that how long the COVID-19 can survive on diverse surfaces. It is also not clear or sure yet that the COVID-19 is transmitted only by droplets of saliva or also by the breath of an infected person. According to WHO contamination through air is for now "hypothetical and reported that the main sources of entry are nasal excretions, saliva, and hand contact with a COVID-19 contaminated surface [16]. Estimated stay time of virus on plastic and steel is 2 to 3 days, 24 and 3 hours on cardboards and in the air respectively [42]. However, this all observations were reported in Laboratory conditions while the outside, the survival of COVID-19 depends on environmental conditions. Cold and humidity are believed to help it in survival. Avoiding crowds and frequent hand washing are still the most effective measures against this pandemic.

\section{The immunity}

Immunity against several viral infections like chicken pox lasts a lifetime, but very short immunity develops due to other types of coronaviruses, so people can infect many times in the same winter due to same. It is necessary to develop a new vaccine in every season. It is important to identify how long the COVID-19 immunity lasts. It is observed that immune response produced by COVID-19 is two phases. The precise adaptive immune response is requisite during incubation to eradicate the virus and to impede the progression of disease to further severe stages [43]. Hence, immune boosting strategies such as PEGylated IFNa or anti-sera are imperative at this stage. Progression of protective immune response as endogenous at the initial incubation stages, good general health of host along with an appropriate genetic background (e.g. Human leukocyte antigen $(\mathrm{HLA})$ ) is important that provokes detailed antiviral immunity [44]. Immune response to pathogen can vary from individual to individual under the umbrella of Genetic differences. In conditions where, impeded the immune response is observed, the virus will proliferate causing the massive obliteration of the affected tissues, particularly in organs with high ACE2 protein, for instance spleen, liver, brain and kidney
[45]. In certain cases, it is very alarming that some patients after getting discharged from hospital still remains show viral positive results. This reflects that in few patients virus-eliminating the immune response to COVID-19 may be challenging to tempt and vaccines may not work with such people. Individuals who improved or recovered from the non-severe stage must be observed for the virus along with the response of T/B cells. It's a high time to keep in mind such scenarios while working or determining the vaccine development strategies.

\section{Prevention}

For optimization of infection control protocols, preventive measures must be focused. The best way to keep you away from virus that is by any mean reduce exposure to the pathogen along with selfisolation. Create distance between yourself and others. Clean the frequently touch surfaces and disinfect them. Patient isolation must be done during the provision of clinical care. According to WHO avoid close contact withother COVID-19 patients, wild and farms animals as well [46]. Cover mouth with cloth or face mask during a cough or sneezing to prevent transmission of aerosol. Often washing of hands for at least 20 seconds particularly when interacting with public gathering, coughing and sneezing. Hand Sanitizers can be used as an alternative measure. Individuals with immunocompromised status are recommended to avoid public gatherings. Strict hygiene measures must be taken by emergency medicine departments for the control of infections. Personnel related to health care professionals must use personal shielding equipment like gown, n95 mask, gloves, FFP3 mask.

\section{Treatment and vaccines}

Until now no effective treatment measures for this pandemic COVID-19 are available having intense safety and efficacy. Most of the doctors and researchers are talking about chloroquine, but nothing has been confirmed until the complete efficacy and safety trials will be reported. Around the world, researchers are working so hardly to find a vaccine, which could take estimated more than a year to be officially development and distribution. [38]. In current scenario; no vaccine still found or none of the specific antiviral drug against COVID-19 infection for potential human therapy. The solitary choice accessible is the use of antiviral drugs such as analogues of Nucleoside and inhibitors of HIV-protease that could reduce viral infection till the availability of specific 
antiviral [26]. It is also reported that remdesivir and chloroquine (broad spectrum antiviral drugs) are also found to be effective in-vitro in controlling infection of COVID-19. Such potent antiviral drugs used in human patients with a safety track record. Therefore, the FDA gave emergency approval to these therapeutic agents to treat COVID-19 infections.

\section{RECOMMENDATION}

The main objective of this review was to addressed what gaps still exist. Many researchers have reported the many common characteristics of COVID-19 virus in comparison with other pandemic viruses, while the major differences are discussed in this review. On the basis of this review, it is recommended that, travel history of all patients with respiratory symptoms must be taken by healthcare providers, along with a history of any international traveling in the last two weeks. Health workers must wear surgical masks and sanitized and wash hands frequently while examining patient's particularly sick people who travelled internationally. Suspected cases must be forwarded to government nominated emergency centers for corona virus for testing and isolation. Regularly used of disinfectants in order to minimize chances of surface adherence. COVID testing kits are very short globally, especially in under developing country, that's why patients coming to hospitals with severe respiratory distress and pneumonia should be quarantined for the recommended time period. All clinicians should be aware of all the latest information regarding COVID-19 outbreak available on website of WHO. Social distancing must be maintained. For the time being international travelling should be avoided. Stay home and maintain a healthy lifestyle by doing exercise and takes healthy food including fruits and vegetables to the immunized health system. People should avoid becoming a carrier in spreading of any rumor or false information about the current status of this disease or virus in order to save the public from anxiety or panic condition. In addition, fear and less care can aggravate the symptoms of this virus. Recently BBC reported that, "Many COVID-19 positive pateints try to hide his infection due to fear and when their symptoms has gotten seriously worse so they visit to the hospital".As a result, large numbers of cases died immediately after arrival in hospital or in the ambulance. So it is much needed to people do not fear to declare them as COVID-19 infected if their test has been positive and try to avoid interaction with other peoples with appropriate care and go for proper treatment.

\section{REFERENCES}

1. Reid AH, Fanning TG, Hultin JV, Taubenberger JK. Origin and evolution of the 1918 "Spanish" influenza virus hemagglutinin gene. Proc. Natl. Acad. Sci. 1999; 96(4):1651-6. Doi:10.1073/pnas.96.4.1651

2. Barro RJ, Ursúa JF, Weng J. The coronavirus and the great influenza pandemic: Lessons from the "spanish flu" for the coronavirus's potential effects on mortality and economic activity. Nat. Bureau of Econ. Res. 2020; 19. Doi:10.3386/w26866

3. World Health Organization (WHO) Novel Coronavirus (2019-nCoV) situation reports-72, 2020. https://www.who.int/emergencies/diseases/novelcoronavirus-2019/situation-reports

4. U.S. Centers for Disease Control and Prevention (CDC) Novel Coronavirus (2019-nCoV) in the U.S. 2020.

https://www.cdc.gov/coronavirus/2019-ncov/casesupdates/cases-in-us.html

5. Coronavirus disease 2019 (COVID-19) pandemic: increased transmission in the EU/EEA and the UK seventh update, 25; 2020. Stockholm: ECDC; 2020.

6. Bordi L, Nicastri E, Scorzolini L, Di Caro A, Capobianchi MR, Castilletti C. et al. Differential diagnosis of illness in patients under investigation for the novel coronavirus (SARS-CoV-2), Italy. Euro Surveill. 2020;25(8):2000170.

Doi:10.2807/1560-7917.ES.2020.25.8.2000170

7. De Wit E, Van Doremalen N, Falzarano D, Munster VJ. SARS and MERS: recent insights into emerging coronaviruses. Nat. Rev. Microbiol. 2016;14(8):523.

Doi: doi:10.1038/nrmicro.2016.81

8. Gonzalez JM, Gomez-Puertas P, Cavanagh D, Gorbalenya AE, Enjuanes L. A comparative sequence analysis to revise the current taxonomy of the family Coronaviridae. Arch. Virol. 2003;148(11):2207-35.

Doi: $10.1007 / \mathrm{s} 00705-003-0162-1$

9. Lai MM, Cavanagh D. The molecular biology of coronaviruses. Adv. Virus Res. 1997;48:1-100. Academic Press.

Doi: 10.1016/S0065-3527(08)60286-9

10. Siddell SG. The coronaviridae. In: The coronaviridae. edn.: Springer; 1995;1-10.

Doi: 10.1007/978-1-4899-1531-3_1

11. Fehr AR, Perlman S. Coronaviruses: an overview of their replication and pathogenesis. In: 
Coronaviruses. edn.: Springer; 2015;1-23. Doi: 10.1007/978-1-4939-2438-7_1

12. Cavanagh D, Brian DA, Enjuanes L, Holmes KV, Lai MM, Laude H. Recommendations of the Coronavirus Study Group for the nomenclature of the structural proteins, mRNAs, and genes of coronaviruses. Virol. 1990;176(1):306-7.

Doi: 10.1016/0042-6822(90)90259-T

13. Javed A, Niazi SK, Ghani E, Saqib M, Janjua HA, Corman VM. et al. Severe acute respiratory syndrome coronavirus 2 isolate SARS-CoV2/Gilgit1/human/2020/PAK, complete genome. 2020. https://www.ncbi.nlm.nih.gov/nuccore/MT240479.1

14. Gabutti G, d'Anchera E, Sandri F, Savio M, Stefanati A. Coronavirus: update related to the current outbreak of COVID-19. Infec. Dis. Ther. 2020;9:24153.

Doi: $10.1007 / \mathrm{s} 40121-020-00295-5$.

15. Huang C, Wang Y, Li X, Ren L, Zhao J, Hu Y. et al. Clinical features of patients infected with 2019 novel coronavirus in Wuhan, China. The Lancet. 2020;395(10223):497-506.

Doi: 10.1016/S0140-6736(20)30183-5

16. World Health Organization (WHO). Rolling updates on Coronavirus disease (COVID-2019) updated on 31 March $2020 . \quad$ Available from: https://www.who.int/emergencies/diseases/novelcoronavirus-2019/events-as-they-happen

17. Novel CP. The epidemiological characteristics of an outbreak of 2019 novel coronavirus diseases (COVID-19) in China. Zhonghua liu xing bing xue za zhi Zhonghua liuxingbingxue zazhi. 2020;41(2):145.

Doi:10.3760/cma.j.issn.0254-6450.2020.02.003

18. Surveillances VJ. The Epidemiological Characteristics of an Outbreak of 2019 Novel Coronavirus Diseases (COVID-19)-China, Zhonghua liu xing bing xue za zhi Zhonghua liuxingbingxue zazhi. 2020;2(8):113-22.

19. Jiang $S$, Du L, Shi Z. An emerging coronavirus causing pneumonia outbreak in Wuhan, China: calling for developing therapeutic and prophylactic strategies. Emerg. Microbes Infect. 2020;9(1):275-7.

Doi: 10.1080/22221751.2020.1723441

20. Lekone PE, Finkenstädt BF. Statistical inference in a stochastic epidemic SEIR model with control intervention: Ebola as a case study. Biometrics. 2006;62(4):1170-7.

Doi: 10.1111/j.1541-0420.2006.00609.x

21. Chen N, Zhou M, Dong X, Qu J, Gong F, Han Y, et al. Epidemiological and clinical characteristics of 99 cases of 2019 novel coronavirus pneumonia in
Wuhan, China: a descriptive study. The Lancet. 2020;395(10223):507-13.

Doi: 10.1016/S0140-6736(20)30211-7

22. Liu Y, Gayle AA, Wilder-Smith A, Rocklöv J. The reproductive number of COVID-19 is higher compared to SARS coronavirus. J. Travel Med. 2020.

Doi: $10.1093 / \mathrm{jtm} / \mathrm{taaa} 021$

23. Shaker MS, Oppenheimer J, Grayson M, Stukus D, Hartog N, Hsieh EW, et al. COVID-19: Pandemic Contingency Planning for the Allergy and Immunology Clinic J. Allergy Clin. Immunol. Prac. 2020.

Doi: 10.1016/j.jaip.2020.03.012

24. Greer AL, Tuite A, Fisman DN. Age, influenza pandemics and disease dynamics. Epidemiol Infect. 2010;138(11):1542-9.

Doi: $10.1017 /$ S0950268810000579

25. Zhou H, Chen X, Hu T, Li J, Song H, Liu Y, et al. A novel bat coronavirus closely related to SARS-CoV2 contains natural insertions at the S1/S2 cleavage site of the spike protein. Curr. Biol. 2020;30:21962203.

Doi: 10.1016/j.cub.2020.05.023.

26. Lu R, Zhao X, Li J, Niu P, Yang B, Wu H, et al. Genomic characterisation and epidemiology of 2019 novel coronavirus: implications for virus origins and receptor binding. The Lancet. 2020;395(10224):56574.

Doi: 10.1016/S0140-6736(20)30251-8

27. World Health Organization (WHO). Coronavirus disease 2019 (COVID-19): situation report, 59. 2020. https://www.who.int/emergencies/diseases/novelcoronavirus-2019/situation-reports

28. Bai Y, Yao L, Wei T, Tian F, Jin DY, Chen L, et al. Presumed asymptomatic carrier transmission of COVID-19. JAMA. 2020.

Doi: 10.1001/jama.2020.2565

29. Woznitza N, Hare SS, Nair A. Covid-19 pandemic: Summary of current and emerging issues for radiographers. Work. 2019;20.

30. Eichner M. Dowell SF, Firese N. Incubation period of Ebola hemorrhagic virus subtype Zaire. Osong Public Health Res. Perspec. 2011;2(1):3-7.

Doi: 10.1016/j.phrp.2011.04.001

31. Lessler J, Reich NG, Brookmeyer R, Perl TM, Nelson KE, Cummings DA. Incubation periods of acute respiratory viral infections: a systematic review. The Lancet Infect. Dis. 2009;9(5):291-300.

Doi: 10.1016/S1473-3099(09)70069-6

32. Lauer SA, Grantz KH, Bi Q, Jones FK, Zheng Q, Meredith HR, et al. The incubation period of 
coronavirus disease 2019 (COVID-19) from publicly reported confirmed cases: estimation and application. Annals Intern. Med. 2020.

Doi: 10.7326/M20-0504

33. Xu Z, Shi L, Wang Y, Zhang J, Huang L, Zhang C, et al. Pathological findings of COVID-19 associated with acute respiratory distress syndrome. The Lancet Res. Med. 2020;8(4):420-2.

Doi: 10.1016/S2213-2600(20)30076-X

34. Zhou F, Yu T, Du R, Fan G, Liu Y, Liu Z, et al. Clinical course and risk factors for mortality of adult inpatients with COVID-19 in Wuhan, China: a retrospective cohort study. The Lancet. 2020.

Doi: 10.1016/S0140-6736(20)30566-3

35. Lan L, Xu D, Ye G, Xia C, Wang S, Li Y, et al. Positive RT-PCR test results in patients recovered from COVID-19. JAMA. 2020.

Doi: 10.1001/jama.2020.2783

36. Hassan S, Sheikh FN, Jamal S, Ezeh JK, Akhtar A. Coronavirus (COVID-19): A Review of Clinical Features, Diagnosis, and Treatment. Cureus. 2020;12(3).

Doi: 10.7759/cureus.7355

37. Wang D, Hu B, Hu C, Zhu F, Liu X, Zhang J, et al. Clinical characteristics of 138 hospitalized patients with 2019 novel coronavirus-infected pneumonia in Wuhan, China. JAMA. 2020;323(11):1061-9.

Doi: 10.1001/jama.2020.1585

38. Lado M, Walker NF, Baker P, Haroon S, Brown CS, Youkee D, et al. Clinical features of patients isolated for suspected Ebola virus disease at Connaught Hospital, Freetown, Sierra Leone: a retrospective cohort study. The Lancet Infec Dis. 2015;15(9):102433.

Doi: 10.1016/S1473-3099(15)00137-1

39. Koliou M, Soteriades ES, Toumasi MM, Demosthenous A, Hadjidemetriou A, Epidemiological and clinical characteristics of influenza $A(H 1 N 1)$ v infection in children: the first 45 cases in Cyprus, June-August 2009. Euro Surveill. 2009;14(33):19312.

Doi: 10.2807/ese.14.33.19312-en

40. Assiri A, Al-Tawfiq JA, Al-Rabeeah AA, Al-Rabiah FA, Al-Hajjar S, Al-Barrak A, et al. Epidemiological, demographic, and clinical characteristics of 47 cases of Middle East respiratory syndrome coronavirus disease from Saudi Arabia: a descriptive study. The Lancet Infec Dis. 2013;13(9):752-61.

Doi: 10.1016/S1473-3099(13)70204-4

41. Kilpatrick AM. Globalization, land use, and the invasion of West Nile virus. Sci. 2011;334(6054):323-7.

Doi: $10.1126 /$ science. 1201010

42. World Health Organization. Household transmission investigation protocol for coronavirus disease 2019 ( COVID-19). World Health Organization; (2020).

43. Shi Y, Wang Y, Shao C, Huang J, Gan J, Huang X, et al. COVID-19 infection: the perspectives on immune responses. Cell Death Differ. March 2020.

Doi: 10.1038/s41418-020-0530-3

44. Whiteside TL. Immune suppression in cancer: effects on immune cells, mechanisms and future therapeutic intervention. InSeminars in cancer biology 2006;16(1):3-15. Academic Press.

Doi: 10.1016/j.semcancer.2005.07.008

45. Ragnarsdóttir B, Lutay N, Grönberg-Hernandez J, Köves B, Svanborg C. Genetics of innate immunity and UTI susceptibility. Nat. Rev. Urol. 2011;8:449.

Doi: 10.1038/nrurol.2011.100

46. Cascella M, Rajnik M, Cuomo A, Dulebohn SC, Di Napoli R. Features, evaluation and treatment coronavirus (COVID-19). InStatPearls [Internet] 2020;8. StatPearls Publishing.

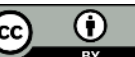

This is an Open Access article distributed under the terms of the Creative Commons Attribution License (http://creativecommons.org/licenses/by/4.0), which permits unrestricted use, distribution, and reproduction in any medium, provided the original work is properly cited. 